\title{
Effects of peak time of myocardial injury biomarkers on mid-term outcomes of patients undergoing OPCABG
}

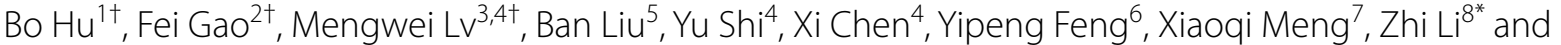 \\ Yangyang Zhang ${ }^{4 *}$
}

\begin{abstract}
Background: With the development of cardiac surgery techniques, myocardial injury is gradually reduced, but cannot be completely avoided. Myocardial injury biomarkers (MIBs) can quickly and specifically reflect the degree of myocardial injury. Due to various reasons, there is no consensus on the specific values of MIBs in evaluating postoperative prognosis. This retrospective study was aimed to investigate the impact of MIBs on the mid-term prognosis of patients undergoing off-pump coronary artery bypass grafting (OPCABG).
\end{abstract}

Methods: Totally 564 patients undergoing OPCABG with normal courses were included. Cardiac troponin T (cTnT) and creatine kinase myocardial band (CK-MB) were assessed within $48 \mathrm{~h}$ before operation and at 6, 12, 24, 48, 72, 96 and $120 \mathrm{~h}$ after operation. Patients were grouped by peak values and peak time courses of MIBs. The profile of MIBs and clinical variables as well as their correlations with mid-term prognosis were analyzed by univariable and multivariable Cox regression models.

Result: Continuous assessment showed that MIBs increased first (12 h after surgery) and then decreased. The peak cTnT and peak CK-MB occurred within $24 \mathrm{~h}$ after operation in $76.8 \%$ and $67.7 \%$ of the patients respectively. No significant correlation was found between CK-MB and mid-term mortality. Delayed cTnT peak (peak cTnT elevated after $24 \mathrm{~h}$ after operation) was correlated with lower creatinine clearance rate $(69.36 \pm 21.67 \mathrm{vs} .82 .18 \pm 25.17 \mathrm{ml} / \mathrm{min} / 1.73$ $\mathrm{m}^{2}$ ), body mass index $\left(24.35 \pm 2.58 \mathrm{vs} .25 .27 \pm 3.26 \mathrm{~kg} / \mathrm{m}^{2}\right)$, less arterial grafts $(1.24 \pm 0.77 \mathrm{vs} .1 .45 \pm 0.86)$, higher EuroSCORE II (2.22 \pm 1.12 vs.1.72 \pm 0.91$)$ and mid-term mortality (26.5 vs.7.9\%). Age (HR: 1.067, Cl: 1.006-1.133), left ventricular ejection fraction (HR: 0.950, Cl: 0.910-0.993), New York Heart Association score (HR: 1.839, Cl: 1.159-2.917), total venous grafting (HR: 2.833, Cl: 1.054-7.614) and cTnT peak occurrence within 24 h (HR: 0.362, Cl: 0.196-0.668) were independent predictors of mid-term mortality.

Conclusion: CTnT is a better indicator than CK-MB. The peak value and peak occurrence of CTnT are related to midterm mortality in patients undergoing OPCABG, and the peak phases have stronger predictive ability. Trial registration:

\footnotetext{
*Correspondence: zhili_cths@163.com; zhangyangyang_wy@vip.sina.com

${ }^{\dagger} \mathrm{Bo} \mathrm{Hu}$, Fei Gao and Mengwei Lv authors contributed equally to this work.

${ }^{4}$ Department of Cardiovascular Surgery, Shanghai East Hospital, School

of Medicine,Tongji University, 150 Jimo Road, Shanghai 200120, China

${ }^{8}$ Department of Cardiovascular Surgery, Jiangsu Province Hospital, The

First Affiliated Hospital of Nanjing Medical University, 300 Guangzhou

Road, Nanjing 210029, China

Full list of author information is available at the end of the article
}

(c) The Author(s) 2021. Open Access This article is licensed under a Creative Commons Attribution 4.0 International License, which permits use, sharing, adaptation, distribution and reproduction in any medium or format, as long as you give appropriate credit to the original author(s) and the source, provide a link to the Creative Commons licence, and indicate if changes were made. The images or other third party material in this article are included in the article's Creative Commons licence, unless indicated otherwise in a credit line to the material. If material is not included in the article's Creative Commons licence and your intended use is not permitted by statutory regulation or exceeds the permitted use, you will need to obtain permission directly from the copyright holder. To view a copy of this licence, visit http://creativecommons.org/licenses/by/4.0/. The Creative Commons Public Domain Dedication waiver (http://creativeco mmons.org/publicdomain/zero/1.0/) applies to the data made available in this article, unless otherwise stated in a credit line to the data. 
Chinese Clinical Trial Registry, ChiCTR2000033850. Registered 14 June 2020, http://www.chictr.org.cn/edit.aspx?pid= $55162 \&$ htm $=4$.

Keywords: Myocardial injury biomarker, Coronary artery bypass grafting, Off pump, Mid-term outcome

\section{Background}

Myocardial injury after cardiac surgery, especially coronary artery bypass grafting (CABG), is inevitable. With the improvement in cardiac surgery techniques, off-pump CABG (OPCABG) has become a favorite choice for surgeons in China [1]. This kind of operation can reduce perioperative myocardial injury, but cannot completely eliminate its incidence. Fortunately, most myocardial injuries are asymptomatic and transient accompanied by the increase of cardiac troponin $\mathrm{T}$ $(\mathrm{cTnT})$ and creatine kinase myocardial band (CK-MB), and only $1-6.4 \%$ of patients are diagnosed with postoperative myocardial infarction [2-5].

Serious myocardial injury is a sensible risk factor for short- and long- term outcomes. CABG is a surgical method of myocardial revascularization, and many factors other than surgical injury can cause myocardial injury, such as reperfusion injury, insufficient myocardial protection, and ischemia. Most studies focus on the relationship between cut-off values of myocardial injury biomarkers (MIBs) and short- and long-term postoperative outcomes [2-7]. Because of the differences in both assessment approaches and patient situations, results of MIBs cut-off values are inconsistent and lack any unified conclusion. Moreover, in the previous studies, MIBs assessments were mostly limited once or twice at a certain time point, and lacked consequent and dynamic observation. The aim of this study was to describe the release profile of perioperative MIBs (including $\mathrm{CTnT}$ and CK-MB) and to investigate effects of these changes on the mid-term prognosis of patients undergoing OPCABG.

\section{Patients and methods \\ Patients}

This was a single-centre, observational, retrospective cohort clinical study. Between September 2009 and December 2014, 1386 consecutive patients underwent cardiac operation in the department of cardiovascular surgery. The inclusion criteria were as follows: 1 . firstly isolated $C A B G ; 2$. no cardiopulmonary bypass (CPB); 3.over 18 years old. The exclusion criteria were as follows: 1 . cardiac surgery other than CABG; 2 . CABG combined with other procedures; 3 . postoperative death; 4. incomplete preoperative MIBs; 5 . lack of postoperative follow-up information (Fig. 1).

Finally 564 patients with normal postoperative courses were enrolled. All patients were operated by the same group of surgeons and received routine treatment and nursing care after operation. All patients signed written informed consents for surgical procedures and participation in this study. The study protocols were approved by the ethics committees of Shanghai East Hospital (ID2019067) with the clinical trial registration number ChiCTR-RRC-19014055.

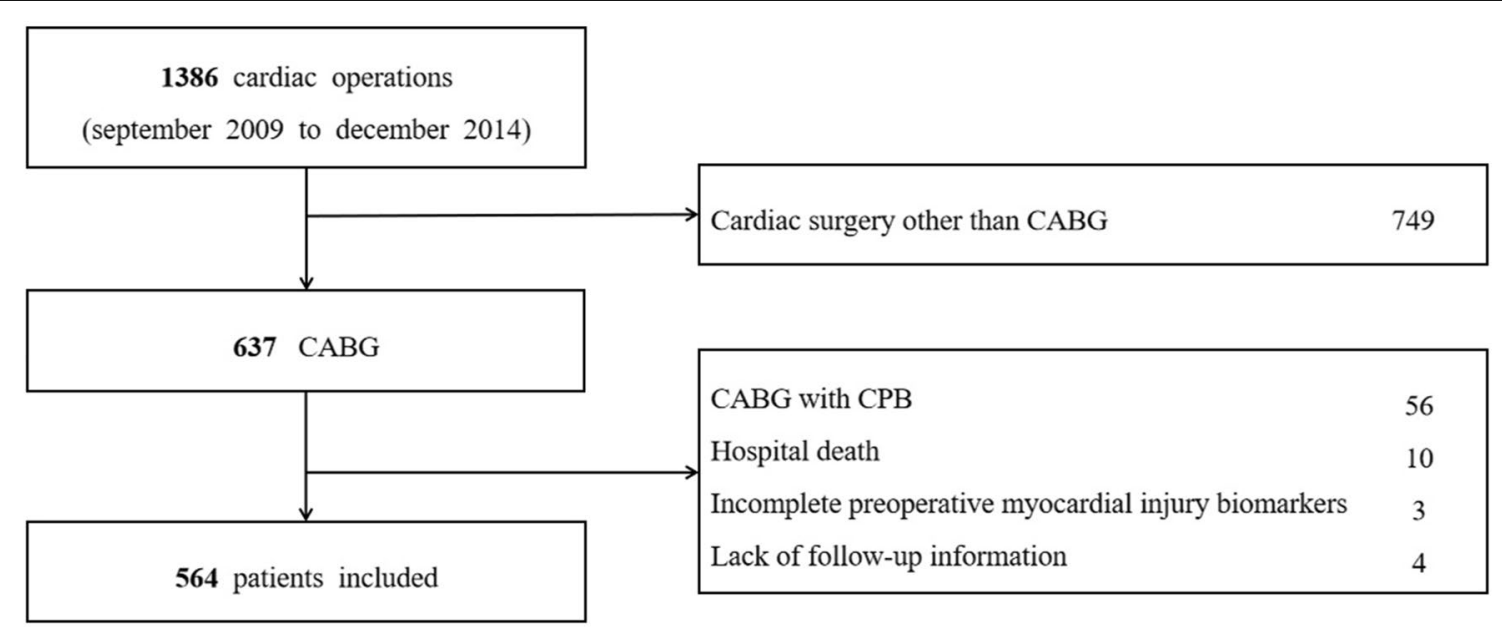

Fig. 1 Flowchart of patients' election 


\section{Cardiac injury biomarker assay}

Blood samples for MIB assay were obtained from venous punctures within $48 \mathrm{~h}$ before operation and at 6, 12, 24, 48, 72, 96 and $120 \mathrm{~h}$ postoperatively. Preoperative MIBs were recorded as baseline values. If a patient recovered well and was discharged within 5 days, MIBs were measured before discharge. MIBs were collected at least until there was a downtrend. Peak values were defined as the highest values measured during postoperative hospitalization. All blood samples were routinely assessed by the same method in the central laboratory of the hospital. The detection limits of cTnT were $0.1-2.0 \mathrm{mg} / \mathrm{l}$ and the normal rang was $<0.1 \mathrm{mg} / \mathrm{l}$. The detection limits of CK-MB were $0-400 \mathrm{mg} / \mathrm{l}$, and the normal range was $0-40 \mathrm{mg} / \mathrm{l}$.

\section{Follow-up}

Patients were followed up in the outpatient clinic or by telephone consultation. The first follow-up was one month after discharge, and the second time was at an interval of 2 months. After that, regular follow-up was conducted every 6 months. All cause mortality was recorded and the median (interquartile range) follow-up time was 76.7 (1.0-126.7) months.

\section{Statistical analysis}

Continuous variables were expressed using mean \pm standard deviation (SD) if they conformed to normal distribution or were expressed using median with interquartile range (IQR). Categorical variables were summarized as absolute numbers and percentages. Statistical comparisons were performed using t-test, Mann-Whitney U tests for continuous variables, and using Fisher's exact or Chi-square tests for categorical variables.

Mid-term mortality was calculated and plotted according to the Kaplan-Meier survival curves. All variables were tested by univariate Cox analysis. Variables with $P<0.08$ were entered into the multivariate analysis. Multivariate Cox regression analysis by using variables from univariate Cox analysis was established to identify the independent risk factors associated with mid-term mortality. Hazard ratios (HR) were expressed with 95\% confidence intervals $(\mathrm{CI})$.

Statistical analysis was performed on SPSS 22.0 for windows (IBM, Chicago, USA).Two-tailed $P<0.05$ was considered significant for all analysis.

\section{Results}

Blood samples were assessed a specific value of MIBs at each monitoring point. The 564 patients had 4163 monitoring points (Some patients recovered well and
Table 1 Clinical characteristics of entire study patients

\begin{tabular}{|c|c|}
\hline Variables & Total $(n=564)$ \\
\hline Male sex (n, \%) & $443(78.5)$ \\
\hline Age $(y)$ & $65.30 \pm 8.20$ \\
\hline Weight (kg) & $70.05 \pm 10.39$ \\
\hline Height (cm) & $166.81 \pm 6.77$ \\
\hline BMI $\left(\mathrm{kg} / \mathrm{m}^{2}\right)$ & $25.13 \pm 3.18$ \\
\hline $\mathrm{BSA}\left(\mathrm{m}^{2}\right)$ & $1.76 \pm 0.16$ \\
\hline \multicolumn{2}{|l|}{ Types of CAD } \\
\hline Unstable angina pectoris (n, \%) & $332(58.9)$ \\
\hline Acute myocardial infarction (n, \%) & $75(13.3)$ \\
\hline Stable angina pectoris (n, \%) & $157(27.8)$ \\
\hline Diabetes mellitus (n, \%) & $201(35.6)$ \\
\hline Hypertension (n, \%) & $413(73.2)$ \\
\hline \multicolumn{2}{|l|}{ Cerebrovascular disease } \\
\hline Stroke $(n, \%)$ & $22(3.9)$ \\
\hline Lacunar infarction (n, \%) & $141(25.0)$ \\
\hline Peripheral vascular disease $(\mathrm{n}, \%)$ & $13(2.3)$ \\
\hline Preoperative atrial fibrillation (n, \%) & $15(2.7)$ \\
\hline Pulmonary hypertension (n, \%) & $12(2.1)$ \\
\hline Serum creatinine $(\mu \mathrm{mol} / \mathrm{l})$ & $82.51 \pm 24.57$ \\
\hline $\operatorname{Ccr}\left(\mathrm{mL} / \mathrm{min} / 1.73 \mathrm{~m}^{2}\right)$ & $80.30 \pm 25.09$ \\
\hline Renal failure $(n, \%)$ & $4(0.7)$ \\
\hline \multicolumn{2}{|l|}{ LVEF (\%) } \\
\hline LVEF $\geq 45 \%(n, \%)$ & $549(97.3)$ \\
\hline LVEF < 45\% (n, \%) & $15(2.7)$ \\
\hline Triple vessel disease (n, \%) & $505(89.5)$ \\
\hline $\operatorname{COPD}(n, \%)$ & $9(1.6)$ \\
\hline Previous PCI (n, \%) & $2(0.4)$ \\
\hline \multicolumn{2}{|l|}{ NYHA } \\
\hline I $(\mathrm{n}, \%)$ & $30(5.3)$ \\
\hline$\|(n, \%)$ & $415(73.6)$ \\
\hline III (n, \%) & $113(20.0)$ \\
\hline IV (n, \%) & $6(1.1)$ \\
\hline EurOSCORE ॥ & $1.79 \pm 0.96$ \\
\hline Operating time (min) & $267.96 \pm 64.04$ \\
\hline Number of bypass grafts ( $n$ ) & $3.70 \pm 1.08$ \\
\hline Number of arterial grafts ( $\mathrm{n}$ ) & $1.42 \pm 0.85$ \\
\hline Number of venous grafts ( $n$ ) & $2.28 \pm 1.12$ \\
\hline Total arterial grafting $(n, \%)$ & $42(7.4)$ \\
\hline Total venous grafting $(\mathrm{n}, \%)$ & $35(6.2)$ \\
\hline Peak of CK-MB (mg/L) & $21.45(15.00,32.00)$ \\
\hline Peak of cTnT (mg/L) & $0.15(0.10,0.34)$ \\
\hline CK-MB peak occurrence within $24 \mathrm{~h}(\mathrm{n}, \%)$ & $382(67.7)$ \\
\hline CK-MB peak value > 32.00 mg/L (n, \%) & $139(24.6)$ \\
\hline Follow-up time (month) & $75.65(59.88,93.58)$ \\
\hline Mid-term mortality (n, \%) & $60(10.6)$ \\
\hline
\end{tabular}

$B M I$ body mass index, $B S A$ body surface area, $C A D$ coronary artery disease, $C C r$ creatinine clearance rate, $L V E F$ left ventricular ejection fraction, COPD chronic obstructive pulmonary disease, $\mathrm{PCl}$ percutaneous coronary intervention, NYHA New York Heart Association, EuroSCORE // European system for cardiac operative risk evaluation II, CK-MB creatine kinase myocardial band, $C T n T$ cardiac troponin $T$ 
were discharged within 5 days after operation), and 3527 monitoring points were completed (3527/4163, 84.7\%). About 557 (557/564, 98.8\%) patients had measurements of MIBs at more than 3 postoperative time points. There were 443 males (78.5\%) and 121 females (21.5\%) who had normal postoperative courses, with a mean age of $65.3 \pm 8.2$ years. Moreover, 60 patients died during the 1.0 to 126.7 (median of 75.7) months of follow-up (Table 1).

\section{MIBs release}

cTnT and CK-MB were measured at 7 monitoring points postoperatively. The release profile of postoperative MIBs increased first and then decreased. The increase of $c \operatorname{TnT}$ was more obvious than that of CK-MB. The median peak values of $\mathrm{cTnT}$ and CK-MB were 0.15 (IQR: $0.10,0.34$ ) $\mathrm{mg} / \mathrm{l}$ and 21.45 (IQR: 15.00, 32.00) $\mathrm{mg} / \mathrm{l}$ respectively. cTnT peaked within $24 \mathrm{~h}$ after operation in $76.8 \%$ of the total cohort (Fig. 2a).Similarly, CK-MB peaked in $67.7 \%$ of patients within $24 \mathrm{~h}$ after surgery (Fig. 2b).

\section{Univariate and multivariate Cox regression analysis}

All clinical variables were entered into univariate analysis. Age, cerebrovascular disease, combined valvular disease, preoperative creatinine clearance rate $(\mathrm{Ccr})$, left ventricular ejection fraction (LVEF), New York Heart Association (NHYA), EuroSCORE II, number of arterial grafts, number of venous grafts, total vein bypass grafting, cTnT peak occurrence within $24 \mathrm{~h}$ and cTnT peak value $>0.34 \mathrm{mg} / \mathrm{l}$ were significantly associated with midterm mortality. In multivariate Cox regression analysis, age, LVEF, NYHA, total venous grafting and cTnT peak occurrence within $24 \mathrm{~h}$ remained significant, and $\mathrm{c} \operatorname{TnT}$ peak occurrence within $24 \mathrm{~h}$ was the strongest predictor (Table 2) (Fig. 3). Interestingly, in multivariate analysis with the same variables but without cTnT peak occurrence within $24 \mathrm{~h}, \mathrm{cTnT}$ peak value $>0.34 \mathrm{mg} / \mathrm{l}$ was a significant independent risk factor $(P=0.015)$. In univariate
Cox analysis, CK-MB-related variables had no significant effect on mid-term mortality (Table 2).

\section{Group classification}

Since CK-MB related variables had no correlation with the end-point events, cTnT related variables had become the research focus. For further evaluation, patients were divided into four groups according to two criteria (peak values and peak time courses of cTnT):

Group I: cTnT peak occurrence within $24 \mathrm{~h}, \mathrm{n}=481$;

Group II: cTnT peak occurrence after $24 \mathrm{~h}, \mathrm{n}=83$;

Group III: cTnT peak value $\leq 0.34 \mathrm{mg} / \mathrm{l}$ ( $75 \%$ percentile), $\mathrm{n}=424$;

Group IV: cTnT peak value $>0.34 \mathrm{mg} / \mathrm{l}$ ( $75 \%$ percentile), $\mathrm{n}=140$.

\section{Perioperative variables}

Patients in group I showed younger age, larger body mass index (BMI), lower serum creatinine, higher Ccr, lower EuroSCORE II, more arterial grafts, less venous grafts, lower CK-MB and cTnT peak values, lower prevalence of CK-MB peak value $>32.00 \mathrm{mg} / \mathrm{l}$, longer follow-up time and lower mid-term mortality compared with group II (Table 3).

Patients in group III had lower prevalence of hypertension, total vein bypass grafting, CK-MB peak occurrence within $24 \mathrm{~h}, \mathrm{CK}-\mathrm{MB}$ peak value $>32.00 \mathrm{mg} / \mathrm{l}$ and lower serum creatinine, higher $\mathrm{Ccr}$, shorter operation time, less venous grafts, lower CK-MB and cTnT peak values, and lower mid-term mortality compared with group IV (Table 4).

\section{Follow-up}

All patients were followed up after discharge. The median follow-up time was 76.7 months. The 1-, 5- and 8 -year survival rates were $98.0 \pm 0.6 \%, 96.6 \pm 0.8 \%$ and
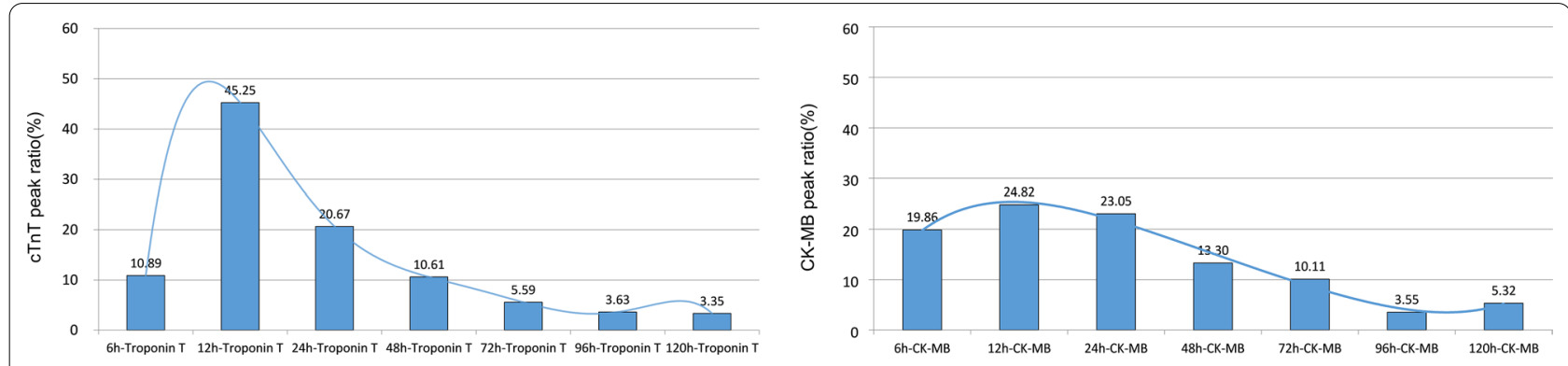

Fig. 2 a Proportion of CTnT peak at each time point after operation. b Proportion of CK-MB peak at each time point after operation 
Table 2 Univariate and multivariate cox regressions analysis for entire study patients

\begin{tabular}{|c|c|c|c|c|c|c|c|c|}
\hline & \multicolumn{2}{|l|}{ Univariate Analysis } & \multicolumn{2}{|c|}{$\begin{array}{l}\text { Multivariate Analysis } \\
\text { excluding (cTnT peak } \\
\text { value }>0.34 \mathrm{mg} / \mathrm{l})\end{array}$} & \multicolumn{2}{|c|}{$\begin{array}{l}\text { Multivariate Analysis } \\
\text { excluding (cTnT peak } \\
\text { occurrence within } 24 \mathrm{~h} \text { ) }\end{array}$} & \multicolumn{2}{|c|}{ Multivariate Analysis (Total) } \\
\hline & $\mathrm{HR}(95 \% \mathrm{Cl})$ & $P$ value & HR (95\% Cl) & $P$ value & $\mathrm{HR}(95 \% \mathrm{Cl})$ & $P$ value & $\mathrm{HR}(95 \% \mathrm{Cl})$ & $P$ value \\
\hline $\operatorname{Sex}(n, \%)$ & $1.043(0.564-1.928)$ & 0.894 & $0.922(0.455-1.868)$ & 0.822 & $1.096(0.550-2.185)$ & 0.795 & $0.933(0.460-1.892)$ & 0.847 \\
\hline Age (y) & $1.097(1.058-1.138)$ & $<0.001$ & $1.060(1.000-1.122)$ & 0.048 & $1.076(1.014-1.141)$ & 0.016 & $1.067(1.006-1.133)$ & 0.031 \\
\hline $\mathrm{BMI}\left(\mathrm{kg} / \mathrm{m}^{2}\right)$ & $0.925(0.850-1.007)$ & 0.071 & $0.976(0.880-1.082)$ & 0.976 & $0.979(0.883-1.084)$ & 0.681 & $0.972(0.876-1.079)$ & 0.595 \\
\hline $\mathrm{BSA}\left(\mathrm{m}^{2}\right)$ & $0.350(0.069-1.775)$ & 0.205 & & & & & & \\
\hline Types of CAD $(n, \%)$ & $0.717(0.473-1.088)$ & 0.118 & & & & & & \\
\hline Diabetes mellitus $(\mathrm{n}, \%)$ & $1.392(0.830-2.333)$ & 0.210 & & & & & & \\
\hline Hypertension $(n, \%)$ & $1.792(0.927-3.462)$ & 0.083 & $1.719(0.855-3.455)$ & 0.128 & $1.732(0.864-3.473)$ & 0.121 & $1.665(0.826-3.358)$ & 0.154 \\
\hline $\begin{array}{l}\text { Cerebrovascular disease } \\
(n, \%)\end{array}$ & $1.815(1.251-2.635)$ & 0.002 & $1.438(0.952-2.172)$ & 0.084 & $1.510(1.005-2.268)$ & 0.047 & 1.464 (0.972-2.205) & 0.068 \\
\hline $\begin{array}{l}\text { Peripheral vascular } \\
\text { disease }(n, \%)\end{array}$ & $0.889(0.123-6.433)$ & 0.907 & & & & & & \\
\hline $\begin{array}{l}\text { Combined valvular } \\
\text { disease }(n, \%)\end{array}$ & $2.385(1.169-4.864)$ & 0.017 & $1.057(0.453-2.466)$ & 0.897 & $1.073(0.456-2.525)$ & 0.871 & $1.081(0.457-2.553)$ & 0.872 \\
\hline $\begin{array}{l}\text { Preoperative atrial fibril- } \\
\text { lation }(n, \%)\end{array}$ & $1.648(0.401-6.765)$ & 0.488 & & & & & & \\
\hline $\begin{array}{l}\text { Pulmonary hyperten- } \\
\text { sion }(n, \%)\end{array}$ & $3.130(0.756-12.951)$ & 0.115 & & & & & & \\
\hline $\mathrm{Ccr}\left(\mathrm{ml} / \mathrm{min} / 1.73 \mathrm{~m}^{2}\right)$ & $0.968(0.955-0.981)$ & $<0.001$ & $0.982(0.963-1.002)$ & 0.076 & $0.982(0.963-1.000)$ & 0.053 & $0.984(0.965-1.003)$ & 0.102 \\
\hline $\operatorname{LVEF}(\%)$ & $0.951(0.918-9.984)$ & 0.004 & $0.951(0.911-0.993)$ & 0.023 & $0.951(0.909-0.994)$ & 0.028 & $0.950(0.910-0.993)$ & 0.022 \\
\hline $\begin{array}{l}\text { Number of diseased } \\
\text { vessels }\end{array}$ & $0.746(0.458-1.215)$ & 0.239 & & & & & & \\
\hline $\operatorname{COPD}(n, \%)$ & $1.133(0.157-8.187)$ & 0.901 & & & & & & \\
\hline Previous PCI $(n, \%)$ & $0.050\left(0.000-1.25^{*} 10 \wedge 9\right)$ & 0.806 & & & & & & \\
\hline NYHA $(n, \%)$ & $2.160(1.403-3.326)$ & $<0.001$ & $1.781(1.125-2.821)$ & 0.014 & 1.903 (1.199-3.019) & 0.006 & $1.839(1.159-2.917)$ & 0.010 \\
\hline EuroSCORE II & $1.695(1.383-2.078)$ & $<0.001$ & $0.816(0.544-1.225)$ & 0.327 & $0.767(0.508-1.156)$ & 0.204 & $0.802(0.533-1.209)$ & 0.292 \\
\hline Operating time (min) & $0.999(0.995-1.003)$ & 0.486 & & & & & & \\
\hline Number of bypass grafts & $0.928(0.723-1.191)$ & 0.558 & & & & & & \\
\hline Number of arterial grafts & $0.388(0.239-0.628)$ & $<0.001$ & $0.964(0.537-1.732)$ & 0.903 & $1.053(0.582-1.906)$ & 0.865 & $0.977(0.540-1.769)$ & 0.939 \\
\hline $\begin{array}{l}\text { Number of venous } \\
\text { grafts }\end{array}$ & $1.311(1.037-1.659)$ & 0.024 & $0.901(0.680-1.193)$ & 0.465 & $0.972(0.734-1.286)$ & 0.841 & $0.898(0.678-1.190)$ & 0.454 \\
\hline $\begin{array}{l}\text { Total artery bypass graft- } \\
\text { ing }(n, \%)\end{array}$ & $0.480(0.150-1.538)$ & 0.217 & & & & & & \\
\hline $\begin{array}{l}\text { Total vein bypass graft- } \\
\text { ing }(n, \%)\end{array}$ & $6.247(3.077-12.683)$ & $<0.001$ & $2.855(1.066-7.647)$ & 0.037 & $3.036(1.133-8.135)$ & 0.027 & $2.833(1.054-7.614)$ & 0.039 \\
\hline CK-MB peak (mg/L) & $1.001(0.995-1.008)$ & 0.670 & & & & & & \\
\hline $\begin{array}{l}\text { CK-MB peak occurrence } \\
\text { within } 24 \mathrm{~h}(\mathrm{n}, \%)\end{array}$ & $0.773(0.461-1.296)$ & 0.328 & & & & & & \\
\hline $\begin{array}{l}\text { CK-MB peak } \\
\text { value }>32.00 \mathrm{mg} / \mathrm{l} \\
(\mathrm{n}, \%)\end{array}$ & $1.452(0.842-2.505)$ & 0.180 & & & & & & \\
\hline cTnT peak (mg/l) & $1.544(0.936-2.546)$ & 0.089 & & & & & & \\
\hline $\begin{array}{l}\text { cTnT peak occurrence } \\
\text { within } 24 \mathrm{~h}(\mathrm{n}, \%)\end{array}$ & $0.243(0.143-0.413)$ & $<0.001$ & $0.318(0.181-0.557)$ & $<0.001$ & & & $0.362(0.196-0.668)$ & 0.001 \\
\hline $\begin{array}{l}\text { cTnT peak } \\
\text { value }>0.34 \mathrm{mg} / \mathrm{L} \\
(\mathrm{n}, \%)\end{array}$ & $1.819(1.073-3.084)$ & 0.026 & & & $2.006(1.145-3.513)$ & 0.015 & $1.400(0.753-2.604)$ & 0.288 \\
\hline
\end{tabular}

$B M I$ body mass index, BSA body surface area, CAD coronary artery disease, $C C r$ creatinine clearance rate, $L V E F$ left ventricular ejection fraction, COPD chronic obstructive pulmonary disease, $P C l$ percutaneous coronary intervention, NYHA New York Heart Association, EuroSCORE II European system for cardiac operative risk evaluation II, CK-MB creatine kinase myocardial band, $\operatorname{CTnT}$ cardiac troponin T 


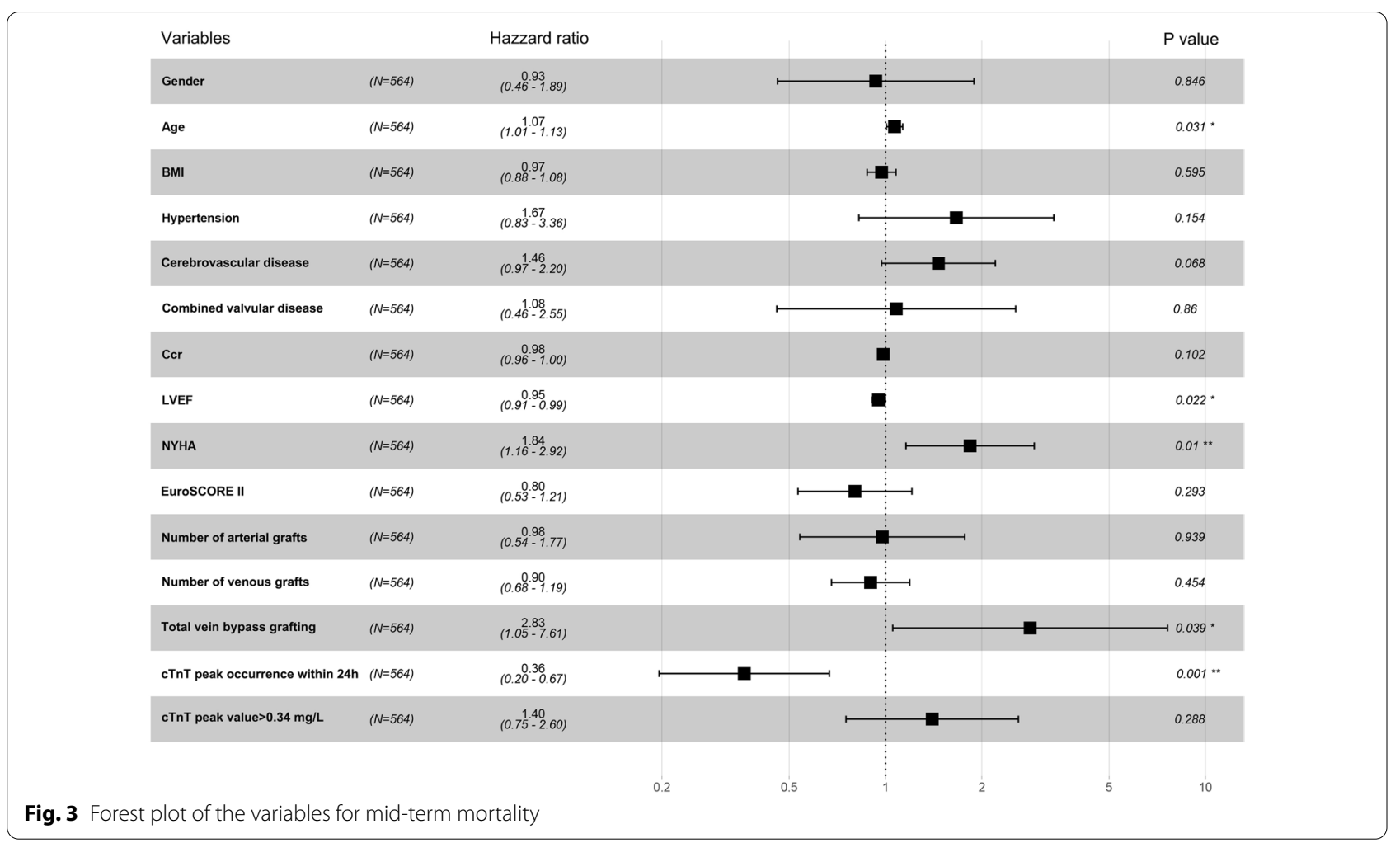

$86.5 \pm 2.0 \%$, respectively. During the follow-up period, 60 patients died, accounting for $10.6 \%$ of the total cohort.

The Kaplan-Meier analyses showed that group I versus group II $(P<0.001)$, and group III versus group IV $(P=0.017)$ had better survival (Fig. $4 \mathrm{a}, \mathrm{b})$.

\section{Discussion}

The time course of MIBs increased first and then decreased after OPCABG. The peak value of cTnT in most patients appeared at $24 \mathrm{~h}$ after surgery. We analyzed the risk factors of mid-term outcome in 564 patients undergoing OPCABG with normal postoperative courses and started from both the peak values and time courses of MIBs. It was found that postoperative peak values and peak occurrence time of cTnT were significant predictors of mid-term mortality. Through literature search and review, we know this is the first report in China to clearly put forward that the peak occurrence time is more predictive than absolute value of peak value in OPCABG patients.

Myocardial injury is an inevitable and common phenomenon during and after CABG. Available literature on this aspect has clearly reported, but not limited to, the insufficient myocardial protection, surgical procedure injuries, ischemia and factors related to patient states
[8-10]. CABG is one of the most common types of cardiac surgery and the number of which is largest in cardiac operation all over the world $[11,12]$. Due to the reduction of extracorporeal circulation procedures, OPCABG fundamentally avoids the problem of myocardial protection. The off-pump pattern can reduce postoperative complications and mortality, which is very suitable for the relatively backward cardiac surgery techniques in China. Therefore, OPCABG is very popular in China, and up to $60 \%$ of severe CAD patients select OPCABG [1]. It is important and significant to better understand the role of MIBs in mid-term prognosis of patients undergoing OPCABG.

MIBs are the important indicators of postoperative myocardial injury in clinical practice. The cTnT with very high sensitivity and specificity is suitable for early warming of myocardial injury [5, 6, 13, 14]. Most of the current articles focus on the relationship between specific peak values of MIBs and short- or long-term prognosis. Due to differences in assessment approaches, time and number of assessment, there is no unified understanding of this issue. Most literature involves only 2-3 measurements at certain time points after operation, including many types of cardiac surgeries and mixed postoperative death cases $[2-5,7$, 
Table 3 Clinical characteristics of patients with cTnT peak occurrence within $24 \mathrm{~h}$ after operation vs. cTnT peak occurrence more than $24 \mathrm{~h}$ after operation

\begin{tabular}{|c|c|c|c|}
\hline Variables & Group I $(n=481)$ & Group II $(n=83)$ & $\mathbf{P}$ \\
\hline Male sex $(n, \%)$ & $380(79.0)$ & $63(75.9)$ & 0.525 \\
\hline Age (y) & $64.77 \pm 8.22$ & $68.41 \pm 7.39$ & $<0.001$ \\
\hline Weight (kg) & $7.035 \pm 10.53$ & $68.30 \pm 9.39$ & 0.097 \\
\hline Height (cm) & $166.73 \pm 6.70$ & $167.29 \pm 7.13$ & 0.487 \\
\hline $\mathrm{BMI}\left(\mathrm{kg} / \mathrm{m}^{2}\right)$ & $25.27 \pm 3.26$ & $24.35 \pm 2.58$ & 0.005 \\
\hline $\mathrm{BSA}\left(\mathrm{m}^{2}\right)$ & $1.76 \pm 0.16$ & $1.74 \pm 0.15$ & 0.231 \\
\hline Types of CAD & & & 0.643 \\
\hline Unstable angina pectoris (n, \%) & $284(59.0)$ & $48(57.8)$ & \\
\hline Acute myocardial infarction (n, \%) & $66(13.7)$ & $9(10.8)$ & \\
\hline Stable angina pectoris $(\mathrm{n}, \%)$ & $131(27.2)$ & $26(31.3)$ & \\
\hline Diabetes mellitus $(n, \%)$ & $164(34.1)$ & $37(44.6)$ & 0.066 \\
\hline Hypertension (n, \%) & $346(71.9)$ & $67(80.7)$ & 0.095 \\
\hline Cerebrovascular disease & & & 0.301 \\
\hline Stroke $(n, \%)$ & $18(3.7)$ & $4(4.8)$ & \\
\hline Lacunar infarction $(n, \%)$ & $115(23.9)$ & $26(31.3)$ & \\
\hline Peripheral vascular disease (n, \%) & $10(2.1)$ & $3(3.6)$ & 0.642 \\
\hline Preoperative atrial fibrillation (n, \%) & $14(2.9)$ & $1(1.2)$ & 0.601 \\
\hline Pulmonary hypertension (n, \%) & $8(1.7)$ & $4(4.8)$ & 0.153 \\
\hline Serum creatinine $(\mu \mathrm{mol} / \mathrm{l})$ & $80.93 \pm 20.31$ & $91.66 \pm 40.35$ & 0.020 \\
\hline $\mathrm{Ccr}\left(\mathrm{ml} / \mathrm{min} / 1.73 \mathrm{~m}^{2}\right)$ & $82.18 \pm 25.17$ & $69.36 \pm 21.67$ & $<0.001$ \\
\hline Renal failure $(n, \%)$ & $2(0.4)$ & $2(2.4)$ & 0.197 \\
\hline LVEF (\%) & & & 0.878 \\
\hline LVEF $\geq 45 \%(n, \%)$ & $468(97.3)$ & $81(97.6)$ & \\
\hline LVEF $<45 \%(n, \%)$ & $13(2.7)$ & $2(2.4)$ & \\
\hline Triple vessel disease $(n, \%)$ & $426(88.6)$ & $79(95.2)$ & 0.069 \\
\hline $\operatorname{COPD}(n, \%)$ & $7(1.5)$ & $2(2.4)$ & 0.868 \\
\hline Previous PCI (n, \%) & $2(0.4)$ & $0(0.0)$ & 1.000 \\
\hline NYHA & & & 0.912 \\
\hline I (n, \%) & $26(5.4)$ & $4(4.8)$ & \\
\hline$\|(n, \%)$ & $356(74.0)$ & $59(71.1)$ & \\
\hline III $(n, \%)$ & $94(19.5)$ & $19(22.9)$ & \\
\hline IV $(n, \%)$ & $5(1.0)$ & $1(1.2)$ & \\
\hline EurOSCORE ॥ & $1.72 \pm 0.91$ & $2.22 \pm 1.12$ & $<0.001$ \\
\hline Operating time (min) & $266.19 \pm 61.80$ & $278.20 \pm 75.37$ & 0.115 \\
\hline Number of bypass grafts ( $n$ ) & $3.67 \pm 1.09$ & $3.87 \pm 1.02$ & 0.119 \\
\hline Number of arterial grafts (n) & $1.45 \pm 0.86$ & $1.24 \pm 0.77$ & 0.028 \\
\hline Number of venous grafts ( $n$ ) & $2.21 \pm 1.12$ & $2.67 \pm 1.03$ & $<0.001$ \\
\hline Total arterial grafting $(n, \%)$ & $40(8.3)$ & $2(2.4)$ & 0.058 \\
\hline Total venous grafting $(n, \%)$ & $26(5.4)$ & $9(10.8)$ & 0.058 \\
\hline Peak of CK-MB (mg/l) & $19.70(14.00,29.05)$ & $32.90(21.00,61.00)$ & $<0.001$ \\
\hline Peak of cTnT (mg/l) & $0.13(0.10,0.26)$ & $0.43(0.25,0.81)$ & $<0.001$ \\
\hline CK-MB peak occurrence within $24 \mathrm{~h}(\mathrm{n}, \%)$ & $327(68.0)$ & $55(66.3)$ & 0.757 \\
\hline CK-MB peak value > 32.00 mg/l (n, \%) & $97(20.1)$ & $42(50.6)$ & $<0.001$ \\
\hline Follow-up time (month) & $77.10(61.00,94.20)$ & $69.10(34.80,86.60)$ & 0.001 \\
\hline Mid-term mortality $(n, \%)$ & $38(7.9)$ & $22(26.5)$ & $<0.001$ \\
\hline
\end{tabular}

$B M /$ body mass index, $B S A$ body surface area, $C A D$ coronary artery disease, $C C r$ creatinine clearance rate, $L V E F$ left ventricular ejection fraction, $C O P D$ chronic obstructive pulmonary disease, $P C$ l percutaneous coronary intervention, NYHA New York Heart Association, EuroSCORE II European system for cardiac operative risk evaluation, CK-MB creatine phosphokinase isoenzyme, $C \operatorname{Tn} T$ cardiac troponin $T$

Group I: CTnT peak occurrence within $24 \mathrm{~h}$ after operation; Group II: cTnT peak occurrence more than $24 \mathrm{~h}$ after operation 
15-17]. Those factors make it difficult to understand the profile of MIBs after surgical performances. In this study, to focus the dynamic changes of MIBs after OPCABG, we excluded death cases and observed the MIBs in a continuous manner at 7 consecutive points after operation.

Due to the distinction in many factors such as instruments, testing approaches and testing environment, there could be absolute differences in the test value of MIBs for patients undergoing cardiac surgery. However, multiple clinical studies have shown that the peak occurrence time did not vary with different testing factors. Using the time of peak as a variable, the absolute value difference could be offset. As reported, the peak cTnT occurred between 24 and $48 \mathrm{~h}$ after cardiac surgery regardless of different testing factors, which was also confirmed by our findings $[4,5$, $9,18]$. In our cohort study, the cTnT peaked at $24 \mathrm{~h}$ after OPCABG in most cases (76.82\%) in the patients with uneventful courses. The proportion of patients whose CK-MB peaked within $24 \mathrm{~h}$ after operation was $67.73 \%$. Patients with maximal peak values had a delayed increase time of peak occurrence, which is similar to another report [15].

Traditional MIBs include cTnT, cTnI and CK-MB. The specificity and sensitivity are higher for both cTnT and cTnI than CK-MB $[5,19,20]$. In this study, although the change trends of CK-MB were similar to those of cTnT, the values and occurrence time of CK-MB peaks were not the risk factors of mid-term mortality (Table 2). This result also reflects that $\mathrm{cTnT}$ is superior over CK-MB [18]. The possible explanations may be that cTnT is more specific and sensitive than CK-MB in myocardial injury. The skeletal muscle injury can also cause the increase of CK-MB [21]. The univariate Cox regression model suggested the value and occurrence time of $\mathrm{cTnT}$ peak were both risk factors of mid-term mortality. The results of the current study suggest that several factors influence the mid-term prognosis of OPCABG. Age, LVEF, NYHA, total vein bypass grafting and $\mathrm{CTnT}$ peak occurrence within $24 \mathrm{~h}$ clearly influence the mid-term mortality. As for the effects of MIBs on the long-term prognosis of CABG patients, Camilla et al. [7] also found the cTnT value at $44 \mathrm{~h}$ postoperatively was more predictive than the values at 7 or $20 \mathrm{~h}$ or the peak values. Unfortunately, they did not make further quantitative analysis or summary. Delayed postoperative elevation of $\mathrm{cTnT}$ suggests the persistent injury of cardiomyocytes after surgery, although there were no obvious clinical symptoms and the patients were discharged safely. This asymptomatic myocardial injury will also affect the long-term survival rate of patients undergoing OPCABG. When other factors in the multivariate Cox regression model were unchanged, the value and occurrence time of cTnT peak were included separately (Table 2). It was found that those two factors were independent risk factors of mid-term mortality. Most of studies only included the peak value when evaluating the risk factors of short- and long-term mortality, and ignored the peak occurrence time $[5-7,22]$. Therefore, the peak value was considered as an independent factor of long-term mortality. Interestingly, when the time of peak occurrence was considered, the results changed. The multivariate Cox regression model including both peak value and peak occurrence time found only the peak occurrence time was an independent risk factor. This also indicates that the peak occurrence time is more predictive of mid-term mortality than the peak value. Delayed elevation of cTnT more greatly impacts mid-term prognosis than early elevation.

\section{Limitation}

There are some limitations in this study. Firstly, the design single-centre retrospective study may cause selection bias. Secondly, the postoperative MIBs were also confected by preoperative myocardial injury (e.g. AMI), which was not considered in the article. Thirdly, the cohort size was small and the incidence of end point events in the follow-up period was also low, which may affect the statistical analysis of the data. Fourthly, the sensitivity and rang of cTnT need to be improved. This limitation will be made up for by the new-generation high-sensitivity cTnT applied in clinic $[6,9]$.

\section{Conclusions}

The peak values and peak phases of postoperative MIBs are both risks factors for mid-term prognosis of OPCABG patients. Our data support the view that the peak phases are more powerful than the peak value in predicting mid-term prognosis. In addition, $\mathrm{cTnT}$ is superior over CK-MB in predicting mid-term prognosis. 
Table 4 Clinical characteristics of patients with cTnT peak value $\leq 0.34 \mathrm{mg} / \mathrm{l}$ vs. cTnT peak value $>0.34 \mathrm{mg} / \mathrm{l}$

\begin{tabular}{|c|c|c|c|}
\hline Variables & Group III $(n=424)$ & Group IV $(n=140)$ & $P$ \\
\hline Male sex (n, \%) & $341(80.4)$ & $102(72.9)$ & 0.059 \\
\hline Age (y) & $65.40 \pm 8.20$ & $64.99 \pm 8.21$ & 0.608 \\
\hline Weight (kg) & $70.33 \pm 10.51$ & $69.18 \pm 10.02$ & 0.255 \\
\hline Height (cm) & $166.92 \pm 6.68$ & $166.48 \pm 7.03$ & 0.502 \\
\hline $\mathrm{BMI}\left(\mathrm{kg} / \mathrm{m}^{2}\right)$ & $25.21 \pm 3.25$ & $24.92 \pm 2.96$ & 0.351 \\
\hline $\mathrm{BSA}\left(\mathrm{m}^{2}\right)$ & $1.77 \pm 0.16$ & $1.75 \pm 0.16$ & 0.256 \\
\hline Types of CAD & & & 0.127 \\
\hline Unstable angina pectoris (n, \%) & $250(59.0)$ & $82(58.6)$ & \\
\hline Acute myocardial infarction (n, \%) & $50(11.8)$ & $25(17.9)$ & \\
\hline Stable angina pectoris (n, \%) & $124(29.2)$ & $33(23.6)$ & \\
\hline Diabetes mellitus (n, \%) & $155(36.6)$ & $46(32 . .9)$ & 0.428 \\
\hline Hypertension (n, \%) & $302(71.2)$ & $111(79.3)$ & 0.062 \\
\hline Cerebrovascular disease & & & 0.525 \\
\hline Stroke $(n, \%)$ & $16(3.8)$ & $6(4.3)$ & \\
\hline Lacunar infarction (n, \%) & $111(26.2)$ & $30(21.4)$ & \\
\hline Peripheral vascular disease (n, \%) & $8(1.9)$ & $5(3.6)$ & 0.249 \\
\hline Preoperative atrial fibrillation (n, \%) & $12(2.8)$ & $3(2.1)$ & 0.661 \\
\hline Pulmonary hypertension (n, \%) & $7(1.7)$ & $5(3.6)$ & 0.172 \\
\hline Serum creatinine $(\mu \mathrm{mol} / \mathrm{l})$ & $80.83 \pm 19.83$ & $87.59 \pm 34.83$ & 0.005 \\
\hline $\operatorname{Ccr}\left(\mathrm{ml} / \mathrm{min} / 1.73 \mathrm{~m}^{2}\right)$ & $81.58 \pm 24.74$ & $76.39 \pm 25.81$ & 0.034 \\
\hline Renal failure (n, \%) & $2(0.5)$ & $2(1.4)$ & 0.242 \\
\hline $\operatorname{LVEF}(\%)$ & & & 0.867 \\
\hline $\operatorname{LVEF} \geq 45 \%(n, \%)$ & $413(97.4)$ & $136(97.1)$ & \\
\hline LVEF $<45 \%(n, \%)$ & $11(2.6)$ & $4(2.9)$ & \\
\hline Triple vessel disease $(n, \%)$ & $379(89.4)$ & $126(90.0)$ & 0.837 \\
\hline $\operatorname{COPD}(n, \%)$ & $7(1.7)$ & $2(1.4)$ & 0.856 \\
\hline Previous PCI (n, \%) & $2(0.5)$ & $0(0)$ & 0.416 \\
\hline NYHA & & & 0.673 \\
\hline I $(n, \%)$ & $25(5.9)$ & $5(3.6)$ & \\
\hline$\|(n, \%)$ & $308(72.6)$ & $107(76.4)$ & \\
\hline III (n, \%) & $86(20.3)$ & $27(19.3)$ & \\
\hline IV $(n, \%)$ & $5(1.2)$ & $1(0.7)$ & \\
\hline EuroSCORE II & $1.75 \pm 0.94$ & $1.92 \pm 1.02$ & 0.075 \\
\hline Operating time (min) & $263.00 \pm 59.08$ & $282.96 \pm 75.44$ & 0.001 \\
\hline Number of bypass grafts ( $n$ ) & $3.68 \pm 1.11$ & $3.76 \pm 0.97$ & 0.446 \\
\hline Number of arterial grafts ( $n$ ) & $1.44 \pm 0.87$ & $1.35 \pm 0.80$ & 0.274 \\
\hline Number of venous grafts ( $n$ ) & $2.22 \pm 1.12$ & $2.44 \pm 1.09$ & 0.044 \\
\hline Total artery bypass grafting $(n, \%)$ & $36(8.5)$ & $6(4.3)$ & 0.100 \\
\hline Total vein bypass grafting ( $n, \%)$ & $22(5.2)$ & $13(9.3)$ & 0.081 \\
\hline Peak of CK-MB (mg/l) & $18.00(13.50,25.00)$ & $41.00(28.30,69.85)$ & $<0.001$ \\
\hline Peak of cTnT (mg/l) & $0.11(0.10,0.18)$ & $0.73(0.44,1.12)$ & $<0.001$ \\
\hline CK-MB peak occurrencewithin $24 \mathrm{~h}(\mathrm{n}, \%)$ & $272(64.2)$ & $114(78.6)$ & 0.002 \\
\hline CK-MB peak value > 32.00 mg/l (n, \%) & $47(11.1)$ & $92(65.7)$ & $<0.001$ \\
\hline Follow-up time (month) & $75.75(60.63,93.34)$ & $75.45(46.05,95.33)$ & 0.578 \\
\hline Mid-term mortality (n, \%) & $37(8.7)$ & $23(16.4)$ & 0.010 \\
\hline
\end{tabular}

$C T n T$ cardiac troponin T, BMI body mass index, BSA body surface area, $C r$ creatinine, $C c r$ creatinine clearance rate, COPD chronic obstructive pulmonary disease, $P C I$ percutaneous coronary intervention, CAD coronary artery disease, NYHA New York Heart Association, LVEF left ventricular ejection fraction, EuroSCORE II European system for cardiac operative risk evaluation II

Group III: Peak of postoperative cTnT $\leq 0.34 \mathrm{mg} /$; Group IV: Peak of postoperative cTnT $>0.34 \mathrm{mg} / \mathrm{l}$ 
a

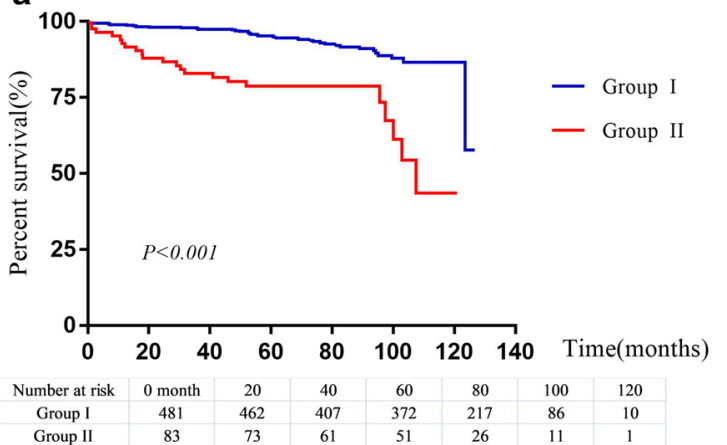

b

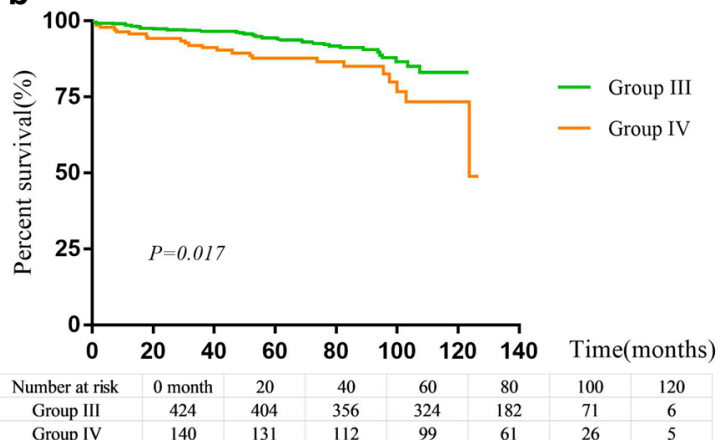

Fig. 4 a Kaplan-Meier survival curves for mortality in group I and group II. b Kaplan-Meier survival curves for mortality in group III and group IV

\section{Acknowledgements}

Not applicable.

\section{Authors' contributions}

BH: Data curation, Writing—Original draft preparation. FG: Data curation, Writing — Original draft preparation. ML: Data curation, Investigation, Formal analysis, Writing — Reviewing and Editing. BL: Data curation, Validation. YS: Validation. XC: Investigation. YF: Investigation. XM: Investigation. ZL: Resources, Writing-Reviewing and Editing, Supervision. YZ: Resources, Conceptualization, Project administration, Writing-Reviewing and Editing, Funding acquisition. All authors read and approved the final manuscript.

\section{Funding}

This research was funded by Shanghai Municipal Natural Science Foundation (No. 20ZR1446100).

\section{Availability of data and materials}

The datasets generated and analyzed during the current study are not publicly available due because it contains patient personal information but are available from the corresponding author on reasonable request.

\section{Declarations}

\section{Ethics approval and consent to participate}

All patients signed written informed consents for surgical procedures and participation in this study. The study protocols were approved by the ethics committees of Shanghai East Hospital (ID2019067) with the clinical trial registration number ChiCTR2000033850. The study protocol was carried out in accordance with the Declaration of Helsinki.

\section{Consent for publication}

Written informed consent for publication of their clinical details was obtained from the patient/parent/guardian/relative of the patient. A copy of the consent form is available for review by the Editor of this journal.

\section{Competing interests}

The authors declare that they have no competing interests.

\section{Author details}

'Department of Cardiology, Shanghai East Hospital, School of Medicine,Tongji University, Shanghai, China. ${ }^{2}$ Cardiovascular Department, Huaiyin Hospital of Huai'an City, Huai'an, China. ${ }^{3}$ Shanghai East Hospital of Clinical Medical College, Nanjing Medical University, Shanghai, China. ${ }^{4}$ Department of Cardiovascular Surgery, Shanghai East Hospital, School of Medicine,Tongji University, 150 Jimo Road, Shanghai 200120, China. ${ }^{5}$ Department of Cardiology, Shangha Tenth People's Hospital, School of Medicine,Tongji University, Shanghai, China. ${ }^{6}$ The First Clinical Medical College of Nanjing Medical University, Nanjing, China. ${ }^{\top}$ The Second Clinical Medical College of Nanjing Medical University, Nanjing, China. ${ }^{8}$ Department of Cardiovascular Surgery, Jiangsu Province
Hospital, The First Affiliated Hospital of Nanjing Medical University, 300 Guangzhou Road, Nanjing 210029, China.

Received: 8 February 2021 Accepted: 8 April 2021

Published online: 24 April 2021

\section{References}

1. Shengshou Hu, Runlin G, Lisheng L, et al. Report on cardiovascular diseases in China 2016. Beijing, China: Encyclopedia of China Publishing House; 2017. p. 210.

2. Carrier M, Pellerin M, Perrault LP, Solymoss BC, Pelletier LC. Troponin levels in patients with myocardial infarction after coronary artery bypass grafting. Ann Thorac Surg. 2000;69(2):435-40.

3. Fransen EJ, Diris JH, Maessen JG, Hermens WT, van Dieijen-Visser MP. Evaluation of "new" cardiac markers for ruling out myocardial infarction after coronary artery bypass grafting. Chest. 2002;122(4):1316-21.

4. Lehrke S, Steen H, Sievers HH, et al. Cardiac troponin T for prediction of short- and long-term morbidity and mortality after elective open heart surgery. Clin Chem. 2004;50(9):1560-7.

5. Peivandi AA, Dahm M, Opfermann UT, et al. Comparison of cardiac troponin I versus $T$ and creatine kinase MB after coronary artery bypass grafting in patients with and without perioperative myocardial infarction. Herz. 2004;29(7):658-64.

6. Mehdiani A, Akhyari P, Kamiya $H$, et al. Prognostic value of the new high sensitive cardiac troponin T assay (hs-cTnT) after coronary artery bypass grafting. Acta Cardiol. 2017;72(3):276-83.

7. Søraas CL, Friis C, Engebretsen KV, Sandvik L, Kjeldsen SE, Tønnessen $\mathrm{T}$. Troponin $\mathrm{T}$ is a better predictor than creatine kinase-MB of longterm mortality after coronary artery bypass graft surgery. Am Heart J. 2012;164(5):779-85.

8. Carlsson AC, Bandstein N, Roos A, Hammarsten O, Holzmann MJ. Highsensitivity cardiac troponin T levels in the emergency department in patients with chest pain but no myocardial infarction. Int J Cardiol. 2017;228:253-9.

9. Ge W, Gu C, Chen C, et al. High-sensitivity troponin T release profile in off-pump coronary artery bypass grafting patients with normal postoperative course. BMC Cardiovasc Disord. 2018;18(1):157.

10. Chung JZ, Dallas Jones GR. Effect of renal function on serum cardiac troponin T-Population and individual effects. Clin Biochem. 2015;48(12):807-10.

11. Liu J, Zhang W, Wang Q, et al. The early diagnostic value of procalcitonin in pneumonia after off-pump coronary artery bypass grafting surgery. Med Sci Monit Int Med J Exp Clin Res. 2019;25:3077-89.

12. Arora RC, Singal RK. Is routine use of renal injury biomarkers in cardiac surgery patients putting the cart before the horse? J Thorac Cardiovasc Surg. 2017;154(3):938-9.

13. Thygesen $K$, Alpert JS, Jaffe AS, et al. Fourth universal definition of myocardial infarction (2018). J Am Coll Cardiol. 2018;72(18):2231-64. 
14. Kouvelos GN, Milionis HJ, Arnaoutoglou EM, et al. Postoperative levels of cardiac troponin versus CK-MB and high-sensitivity C-reactive protein for the prediction of 1-year cardiovascular outcome in patients undergoing vascular surgery. Coron Artery Dis. 2011;22(6):428-34.

15. Tevaearai Stahel HT, Do PD, Klaus JB, et al. Clinical relevance of troponin t profile following cardiac surgery. Front Cardiovasc Med. 2018;5:182.

16. Nesher N, Alghamdi AA, Singh SK, et al. Troponin after cardiac surgery: a predictor or a phenomenon? Ann Thorac Surg. 2008;85(4):1348-54.

17. Lurati Buse GA, Bolliger D, Seeberger E, et al. Troponin T and B-type natriuretic peptide after on-pump cardiac surgery: prognostic impact on 12-month mortality and major cardiac events after adjustment for postoperative complications. Circulation. 2014;130(12):948-57.

18. Sadony V, Körber M, Albes G, et al. Cardiac troponin I plasma levels for diagnosis and quantitation of perioperative myocardial damage in patients undergoing coronary artery bypass surgery. Eur J Cardiothorac Surg. 1998;13(1):57-65.
19. Weidenmann $V$, Robinson NB, Rong LQ, et al. Diagnostic dilemma of perioperative myocardial infarction after coronary artery bypass grafting: a review. Int J Surg. 2020;79:76-83.

20. Li X, Shan L, Lv M, et al. Predictive ability of EuroSCORE II integrating cardiactroponin T in patients undergoing OPCABG. BMC Cardiovasc Disord. 2020;20(1):463.

21. Tsung JS, Tsung SS. Creatine kinase isoenzymes in extracts of various human skeletal muscles. Clin Chem. 1986;32(8):1568-70.

22. Vikenes K, Andersen KS, Melberg T, Farstad M, Nordrehaug JE. Long-term prognostic value of cardiac troponin I and $T$ versus creatine kinase-MB mass after cardiac surgery in low-risk patients with stable symptoms. Am J Cardiol. 2010;106(6):780-6.

\section{Publisher's Note}

Springer Nature remains neutral with regard to jurisdictional claims in published maps and institutional affiliations.
Ready to submit your research? Choose BMC and benefit from:

- fast, convenient online submission

- thorough peer review by experienced researchers in your field

- rapid publication on acceptance

- support for research data, including large and complex data types

- gold Open Access which fosters wider collaboration and increased citations

- maximum visibility for your research: over $100 \mathrm{M}$ website views per year

At BMC, research is always in progress.

Learn more biomedcentral.com/submissions 